\title{
A HYBRID QUALITY FUNCTION DEPLOYMENT AND CYBERNETIC ANALYTIC NETWORK PROCESS MODEL FOR PROJECT MANAGER SELECTION
}

\author{
Farahbod MOHAMMADI ${ }^{a}$, Mohammadali Kazerooni SADI ${ }^{b}$, Fatemeh NATEGHI ${ }^{c}$, \\ Arham ABDULLAH ${ }^{\mathrm{d}}$, Martin SKITMORE ${ }^{\mathrm{e}}$ \\ ${ }_{a, b, c, d}$ Department of Structure and Materials, Faculty of Civil Engineering, \\ Universiti Tekknologi Malaysia, 81310, Johor, Malaysia \\ ${ }^{e}$ School of Civil Engineering and Built Environment, Queensland University of Technology, \\ GPO Box 2434, Brisbane, Q4001, Australia
}

Received 18 Dec 2013; accepted 28 May 2014

\begin{abstract}
Identifying appropriate decision criteria and making optimal decisions in a structured way is a complex process. This paper presents an approach for doing this in the form of a hybrid Quality Function Deployment (QFD) and Cybernetic Analytic Network Process (CANP) model for project manager selection. This involves the use of QFD to translate the owner's project management expectations into selection criteria and the CANP to weight the expectations and selection criteria. The supermatrix approach then prioritises the candidates with respect to the overall decision-making goal. A case study is used to demonstrate the use of the model in selecting a renovation project manager. This involves the development of 18 selection criteria in response to the owner's three main expectations of time, cost and quality.
\end{abstract}

Keywords: Cybernetic Analytic Network Process (CANP), Quality Function Deployment (QFD), QFD-ANP, project manager selection.

\section{Introduction}

Every owner, consultant, and contractor is alert to the need for good project managers, making the task of finding the right project manager for a construction project a critical one for all concerned (Ogunlana et al. 2002). For construction companies, project managers play a challenging and dynamic role (Ochieng et al. 2013) and successful construction organizations focus on ensuring they have project managers with sufficient core competencies (Hwang, Ng 2013). There is a growing recognition, though, that different types of projects require different management approaches, different project management skills and capabilities, and with procedures tailored to the needs of the project (Müller, Turner 2007). Thus, the selection of project managers needs careful consideration. However, it is not easy to identify a suitable person (Kerzner 2001; Rashidi et al. 2011) and current project manager selection methods are known to be inefficient and carry little validity (Rashidi et al. 2011). Although the selection process can be based on the knowledge, preferences and experiences of the decision maker, a more systematic approach is needed (Hsu, Hu 2009). The development of a structured system would be extremely beneficial.

On the other hand, a review of the literature shows that, while many decision models are available for supplier, contractor and sub-contractor selection, conside- rably less attention has been paid to project manager selection. The traditional interview based project manager selection has been criticized because of its time consuming process and possibility of overlooking a qualified candidate (Jazebi, Rashidi 2013; Rashidi et al. 2011). In addition interviewing is highly subjective and the interviewer may not be sufficiently experienced in interview based decision making to make an accuracy final decision.

In response to these issues, Hadad et al. (2013) propose a decision support system based on Data Envelopment Analysis and the Mann-Whitney-Wilcoxon U test to select candidates according to past performance. Lau (2006) has defined a set of project manager selection criteria and developed an AHP-based project manager selection model. Afshari et al. (2012) developed a decision model-based Fuzzy Simple Additive Weighing (FSAW) approach to select construction project managers. In summary, the review of the literature revealed very few decision models have been developed for project manager selection and the available decision models that focus on handling subjectivity and complexity of project manager selection lack in two major aspects; the inner dependency of decision elements and accommodating project client demands during model development.

This paper develops a decision model based on Quality Function Deployment (QFD), a customer oriented design tool that enables decision makers to systematically identify project client demands and translate their needs 
into project manager selection criteria while also taking into account the inter and inner dependencies among decision elements. In addition, Cybernetic Analytic Network Process (CANP) is employed to derive the weights of the client's needs, prioritizing project manager selection criteria, the degree of correlation between decision elements (client's needs and selection criteria) and the overall ranking of project manager candidates.

\section{Quality Function Deployment (QFD)}

QFD is a quality management tool that focuses on customer satisfaction. It is a cross-functional planning tool that ensures customer needs are meaningfully translated into design requirements through a systematic process. QFD was initially conceptualized in the late 1960s and first implemented in the Kobe shipyards of Mitsubishi Heavy Industries Ltd. (Akao 1972). A complete QFD process contains a set of four interconnected tables for: (1) product planning or house of quality (HoQ); (2) part deployment; (3) process planning; and (4) production planning (Liu, Wang 2010). Although QFD has been widely used in manufacturing for quality improvement, it has recently been adopted by the construction industry as a decision making tool for variety of purposes, including supplier selection (Bevilacqua et al. 2006; Taghizadeh 2013), selecting best marketing strategies (Dikmen et al. 2005), contractor selection (Juan et al. 2009) and better architectural design (Gargione 1999; Serpell, Wagner 1997; Yang et al. 2003).

When used as an aid for selection decisions, a twostage process is envisioned. In the first stage of QFD, $\mathrm{HoQ}$, aims at prioritizing engineering characteristics. This involves four steps: prioritizing important customer demands (WHATs), determining engineering characteristics or the way in which customer demands are met (HOWs), development of a relationship matrix between the WHATs and HOWs and two separate correlation matrices between the elements of the WHATs and the elements of the HOWs. When QFD tables are used for the purpose of project manager selection, the project client is regarded in the HoQ as a customer who, with the aid of experts, has his/her requirements translated into selection criteria. Like an engine, the HoQ derives the priority of the engineering characteristics. A second table of QFD then evaluates candidates against these prioritized selection criteria to obtain the priority order of the candidates themselves.

Conventional QFD has several shortcomings, however (Lee et al. 2010). A particular problem is its inability to deal adequately with interdependencies and the provision of feedback. A recent extension aimed at overcoming this is the incorporation of the Analytic Network Process (ANP) into QFD. ANP is a multiple criteria decision-making (MCDM) method that is able to model the whole process of QFD and derive the final priorities of alternatives, with the quantification process of QFD being regarded as decision problem.

\section{Incorporating ANP into QFD}

ANP is a generalized form of Saaty's widely used decision theoretic Analytic Hierarchy Process (AHP) and is incorporated into QFD in order to model the whole process of QFD and prioritise customer needs (Bhattacharya et al. 2005; Partovi, Corredoira 2002; Abastante, Lami 2012; Ertay et al. 2005; Kahraman et al. 2006; Karsak et al. 2003; Lee, Lin, 2011; Lin et al. 2010; Liu, Wang 2010; Liu, Tsai 2012; Pal et al. 2007; Raharjo et al. 2008). In contrast with AHP, which decomposes decision problems into a hierarchical order, ANP uses a network of interactions and supermatrix (Saaty 2008). Generally, problem solving with ANP is performed in four steps: developing a network depicting the problem, knowledge acquisition through pairwise comparisons and estimation of local priority vectors, supermatrix formation and analysis and ranking of decision alternatives (Asan et al. 2012). The analysis for ranking decision alternatives if ANP is incorporated into QFD can be performed by two general methods, either simple matrix manipulation or by the supermatrix approach (Lee et al. 2010; Raharjo et al. 2008); simple matrix manipulation is more appropriate when the number of clusters is limited to two. On the other hand, the application of the supermatrix approach is more appropriate when solving a complex decision problem involving interdependencies and dynamic feedback. Furthermore, the supermatrix is more versatile and eases the calculation of the final priorities (Raharjo et al. 2008; Lee et al. 2008). The next section discusses in detail the steps and methodology of ANP-QFD used in decision making.

\section{Decision model}

The model proposed in this paper is divided into three main phases: (i) problem decomposition, whereby a meaningful ANP network for a two stage QFD mode is created; (ii) knowledge acquisition with the aid of a cybernetic pair-wiser framework; and (iii) overall ranking of decision alternatives through the analysis of a supermatrix (Mohammadi et al. 2014). These phases are explained in the following sections.

\subsection{Decomposition of the model}

The problem decomposition of QFD-based project manager selection starts by identifying and prioritizing the project client's (owner) demands. Depending on project size and ownership type (government, private or mixed) the client can be an individual or group of individuals who need to appoint a project manager in order to secure his/her/their interests. These interests can be identified with the aid of a structured interview or open-ended questionnaire survey. Clients usually express their demands in vague terms. For instance, in saying "I do not want to see any fatal or nonfatal injuries" the client is actually expressing its willingness to keep project safety risk at as low a level as is practicable. All such requirements should be precisely recorded and then, with the aid of clustering techniques, grouped and translated into meaningful terms. A team of experts familiar with project management knowledge is needed to 
perform the translation process. Once the real client's interests are identified then this team determines the project manager specialities needed in order to serve the client's interests. In other words, at this point another translation is performed to determine the measures upon which the client's interests are managed.

When only one HoQ is modelled with ANP, the decision network is similar to that shown in the first two level of Figure 1 (Karsak et al. 2003). However, when two stages of QFD process are involved, the network representing the entire model has four levels (Lee et al. 2008). Generally the number of levels of a 1,2,3 and 4 phase QFD model are 3, 4, 5 and 6, respectively. QFD based project manager selection is a two stage QFD modelling, with the second, third, and forth levels represent client's expectations, selection criteria and candidates respectively. In this type of network, the second and third levels play the role of criteria and sub-criteria in an ANP decision model. The goal occupies the first level of the network and prioritises the decision criteria (client's expectations).

The arcs in the model represent the inner dependencies or inner relationships between decision elements. The relationships in each level should therefore be identified. There are several qualitative methods that help to define the relationships between decision elements, such as the Delphi technique, Interpretive Structural Modelling (ISM), Card Sorting and focus group discussions. Here, ISM is used as a structured way of understanding the interactions between decision elements in a complex system. The application of ISM during the problem decomposition stage helps to define all possible relationships between elements - first in the second level (criteria) and then in the third level (sub-criteria) of the decision model. Note that in the second QFD table (fourth level of ANP model) there is no correlation between candidates. This is because the candidates are regarded as decision alternatives and are independent of each other therefore no arc is drawn Figure 1.

\section{Interpretive Structural Modelling (ISM)}

ISM was first proposed by Warfield (1974). It is an effective tool for analysing a complex system and identifying how an element of a complex system can interact. The foundation of this method is in graph theory and mathematics and it generally helps to have a better understanding of a complex system by dividing the system into several sub-systems. A complete ISM involves five main steps:

(a) Identifying the variables that make the system complex - in this case, the client's real demands (second level) and selection criteria (third level);

(b) Forming a contextual relationship matrix to show the relationship between the variables. For every pair of variables, the group of experts are asked to respond to the question: "Is there any relationship between element A and B? If the answer is yes, please select the correct proposition:

$1-$ A helps to achieve B?

2 - B helps to achieve A?".

The literature offers no guidance on the number of experts (sample size) that should participate in ISM. However ISM is a qualitative technique, the aim of which is the development of a hypothetical structural model which can be further validated statistically with the aid of structural equation modelling (SEM) when generalization is the main objective (Singh, Kant 2007; Chandramowli et al. 2011; Faisal et al. 2006). In addition, 3-7 experts are usually consulted in ISM work (Kumar et al. 2013; Gorane, Kant 2013; Azevedo et al. 2013). Clearly for every pair of variables $\mathrm{K}$ (the number of experts involved in the process) answers will be received. In order to form a consensus, a simple algorithm is proposed as follows.

It is assumed a consensus has been reached when at least $80 \%$ of the answers agree on the existence or nonexistence of a relationship between two variables. Where there is less than $80 \%$ agreement, the experts are required to provide at least one reason why they made their judgment. A group discussion then takes place after which the experts are asked to change their judgment if they found it necessary. Consensus is taken to have been reached if there is at least $60 \%$ agreement on the existence or non-existence of relationship between the pairs of variables. The process is then repeated with the remaining pairs of variables until a consensus exists for every pair.

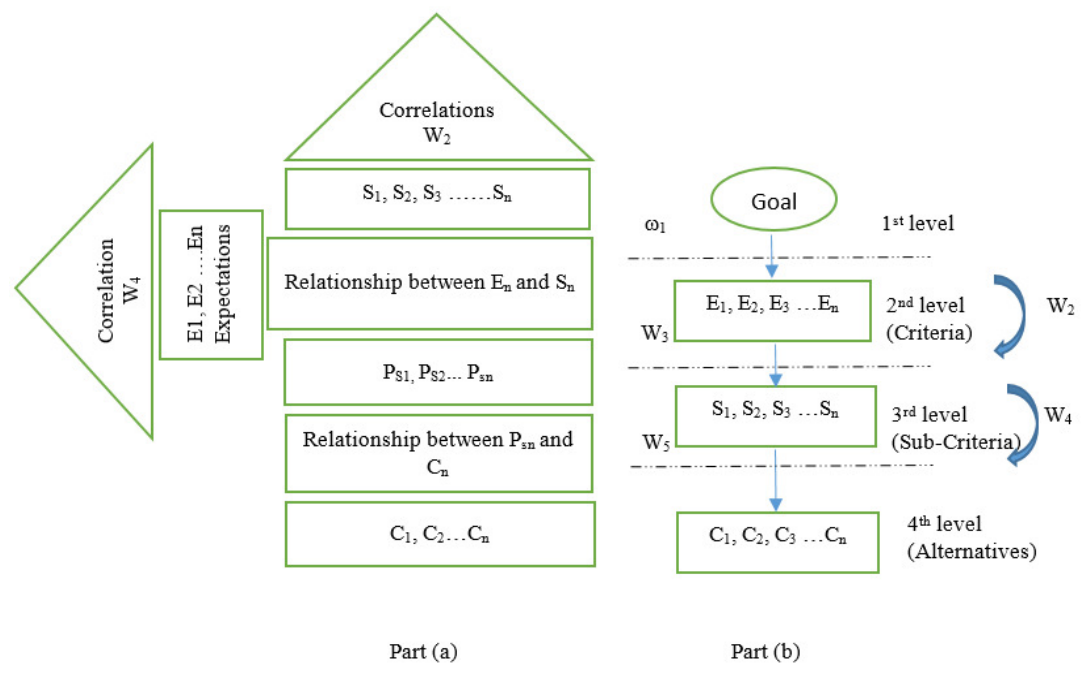

Fig. 1. A two stage QFD model and its representative ANP network 
Once the relationships between the variables are established in this way, the aggregated qualitative group judgments are transferred into a contextual relationship matrix $A_{i j}$. For each two elements in row $i$ and column $j$ of this matrix the quantitative value of 1 is assigned if the experts agreed upon the existence of relationship $\left(R_{i j}\right)$; zero otherwise;

(c) Forming the transitive reachability matrix. Transitivity means that when A has relationship with $\mathrm{B}$ and $\mathrm{B}$ has relationship with $\mathrm{C}$ then $\mathrm{A}$ should necessarily have relationship with $\mathrm{C}$. To form transitive matrix formula (1), Boolean multiplication and addition is applied $(1+$ $1=1^{*} 1=1+0=0+1=1,1^{*} 0=0 * 1=0$ ). The transitive matrix is achieved when two consecutive matrixes become identical:

$$
\begin{aligned}
& \begin{array}{lllllll} 
& V_{1} & V_{2} & \cdot & \cdot & \cdot & V_{n} \\
V_{1} & 0 & & & & &
\end{array} \\
& A_{i j}=\begin{array}{cccc}
V_{2} & 0 & & \\
. & & 0
\end{array}
\end{aligned}
$$

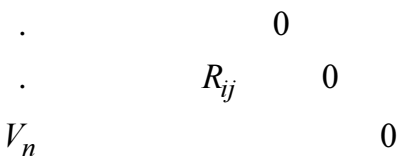

where $V_{i j}$ denotes the contextual relationship matrix of variables, $V$ denotes the variable, $R_{i j}$ denotes the relationship between variables $i$ and $j(i, j=1,2,3, \ldots, m)$ :

$$
A_{t}=\left(A_{i j}+I\right)^{n} \text {, }
$$

where: $n=1,2,3, \ldots, m$ and $I$ is the identity matrix;

(d) Depicting the network of interactions (ANP model) in the second and third level; using the transitive reachability matrix, which is a binary matrix comprising 0 and 1 , an arrow pointing from $V_{2}$ (column element) to $V_{1}$ (row element) is drawn if the corresponding cell $R_{\odot}=1$.

\subsection{Knowledge acquisition under a Pair-Wiser framework}

In this step, since the network and its interactions have been depicted, pairwise comparisons are performed to estimate: (a) the local priority vectors $\omega_{1}$ in which client's interests are compared pairwise with respect to the overall goal; (b) following the concept of a quality chart, HoQ looks like a house, correlation matrices $\left(W_{4}\right.$ and $\left.W_{2}\right)$, the roof and porch of HoQ are formed. Note that the relationships between the variables of the two matrices are identified with the aid of ISM; (c) since two stages of QFD are being modelled in ANP two relationship matrices should be formed. The first is the relationship matrix between the client's interests and selection criteria $\left(W_{3}\right)$ and the second is the relationship matrix of candidates and selection criteria $\left(W_{5}\right)$. In order to form these matrices, in both QFD, the relative dominance of element $i$ over $j$ with respect to a control criterion are estimated. However, ANP/AHP data collection is always an arduous task, especially when a large number of pairwise decision elements are involved. Recently, however, Chen (2010) has proposed a new cybernetic model of ANP in which only $N$ comparisons instead of $N(N-1) / 2$ pairwise comparisons are performed, which considerably eases the situation.

The concept of pairwise comparisons is to measure the dominance of two elements or two clusters at the same time. Experts are asked to answer the generic question of: given a control criterion (sub-criterion), a component (element) of the network, and given a pair of components (elements), how much more does a given member of the pair influence that component (element) with respect to the control criterion (sub criterion) than the other member? (Saaty, Vargas 2001). In contrast, with the cybernetic model, experts are asked to assume that all decision criteria to be compared in pairs are in a table and to score all the elements on a scale of 1-9 with respect to their common properties. Following the rules given in Table 1, which Chen (2010) calls Pair-Wiser rules, for every two elements the difference between given scores for each pair of elements represents the amount of domi-

\begin{tabular}{|c|}
\hline IF PC $=i: j$ and $i-j=0$ THEN $\mathrm{PJ}_{\mathrm{ij}}=$ Equally do \\
\hline $\begin{array}{c}\mathrm{IF} \mathrm{PC}=i: j \text { and } i-j=1 \text { THEN } \mathrm{PJ}_{\mathrm{ij}}=\underset{\text { Equal to moderately }}{\text { dominant }}\end{array}$ \\
\hline IF PC $=i: j$ and $i-j=2$ THEN PJ $\mathrm{Jij}_{\mathrm{ij}}=$ Moderately dominant \\
\hline IF PC $=i: j$ and $i-j=3$ THEN $\mathrm{PJ}_{\mathrm{ij}}=\begin{array}{c}\text { Moderately to strongly } \\
\text { dominant }\end{array}$ \\
\hline IF $\mathrm{PC}=i: j$ and $i-j=4 \mathrm{THEN} \mathrm{PJ}_{\mathrm{ij}}=$ Strongly dominant \\
\hline IF PC $=i: j$ and $i-j=5$ THEN $\mathrm{PJ}_{\mathrm{ij}}=\begin{array}{c}\text { Strongly to very strong } \\
\text { dominant }\end{array}$ \\
\hline 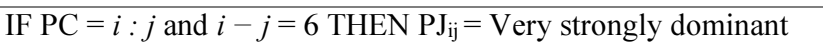 \\
\hline $\begin{array}{c}\mathrm{IF} \mathrm{PC}=i: j \text { and } i-j=7 \mathrm{THEN} \mathrm{PJ}_{\mathrm{ij}}=\underset{\text { Very strong to extremely }}{\text { dominant }}\end{array}$ \\
\hline
\end{tabular}
nance of element $i$ over element $j$.

Table 1. Pair-Wiser rules*

*Where PC and PJ denote paired comparison and pairwise judgments. Scores $(i$ and $j$ ) are given on the scale of 1 to 9 , where: 1 = Not important, 2 = Not to moderately important, $3=$ Moderately important, $4=$ Moderately to strongly important, $5=$ Strongly important, $6=$ Strongly to very strongly important, $7=$ Very strongly important, $8=$ Very strongly to extremely important, $9=$ Extremely important.

Once judgments based on Pair-Wiser rules are made and then translated into pairwise comparisons, the principal eigenvector is the priority vector of a consistent matrix (Saaty 2003), and the relative dominance or priority vector of the decision elements is estimated by solving:

$$
A \cdot W=\lambda_{\max } \cdot W,
$$

where: $A$ is the Pairwise comparison matrix, $W$ is the eigenvector and $\lambda_{\max }$ is the largest eigenvalue of $A$.

After estimating the priority vectors, the consistency of judgments should be checked. This is because the priority vector values in ANP decision theory are estimated, rather than precise, values. The inconsistency in each comparison matrix should to be no greater than $10 \%$ to be acceptable (Saaty 1990), which means a consistency ratio (CR) of less than 0.1. Therefore, if $\mathrm{CR}>0.1$ judgments 
are considered to be inconsistent and the experts should be asked to revise their judgments. This is an iterative process and terminates when all the matrices have an acceptable consistency ratio.

\subsection{Supermatrix formation and analysis}

In conventional QFD, each HoQ is quantified separately. The priorities of the HOWs obtained in the first HoQ is then transferred to the next quality chart (HoQ) and are regarded as priorities of WHATs. When the number of HoQ is increased, in practice the number of computations is also increased - making the quantification process more subjective and problematic. The supermatrix of ANP, however is able to compute and facilitate quantification of multiple HoQs in one single matrix. The supermatrix generally shows the influence priority of the decision elements on the left of the matrix over an element at the top of matrix (Saaty 2004). Obtaining the overall priorities of decision alternatives with respect to goal is a quite difficult. After forming the supermatrix, the priority vectors and pairwise comparison matrices are transferred into corresponding cells in order to form an unweighted supermatrix. Note that, decision network of QFD is not a pure ANP network (a network wherein the goal does not exist and the priorities of decision criteria are driven by pairwise comparison of the criteria with respect to alternatives or other criteria-feedback) but is a special type of hierarchical thinking structure wherein inner dependence exist between decision elements. When a hierarchical structure is solved with ANP, the identity matrix of $I$ is added in the last row and column of the unweighted supermatrix (Saaty 2004). Three steps are then followed in order to estimate the final priority of decision alternatives: (1) normalizing each column of the unweighted supermatrix in order to obtain a column stochastic matrix; and (2) raising this matrix to the power of a large arbitrary number to obtain the limit supermatrix with steady status (3). According to Saaty (2009), since the priorities of intermediate decision elements after raising the weighted supermatrix power shifts to zero, to display the priorities of decision criteria, sub-criteria and alternatives with respect to the overall goal, sum the $1^{\text {st }}, 2^{\text {nd }} \ldots$ and $N^{\text {th }}$ power of supermatrix then the final matrix should be column normalized to one again. This matrix is where the priorities of decision criteria, sub-criteria and alternatives with respect to the overall goal are displayed.

Based on the network illustrated earlier, supermatrix $W$ is given by:

$\begin{array}{ccccc} & \text { Goal } & \text { Criteria } & \text { Su-Criteria } & \text { Alts } \\ \text { Goal } & 0 & 0 & 0 & 0 \\ \text { Criteria } & \omega 1 & W 2 & 0 & 0 \\ \text { Sub-Criteria } & 0 & W 3 & W 4 & 0 \\ \text { Alts } & 0 & 0 & W 5 & 1\end{array}$

\section{Case study}

In Malaysia, refurbishment and renovation work are categorized as demolition projects based on the definition in the MS2318:2012 Malaysian Code of Practice for Build- ing Demolition (2012). Although its contribution to the economy in terms of turnover is almost half that of construction (Davidson, Leather 2000), it is labour intensive, very technical, complex in nature and involves many risky activities (Egbu 1999). The Jaya Supermarket and Terengganu Stadium collapse, for example, are two tragic demolition accidents which resulted in a number of fatal and non-fatal injuries (Michael, Razak 2013). Compared with the equivalent in developed countries, the demolition industry in Malaysia is considered to be immature; however, it is a fast growing industry. Because of the challenging nature of this industry wherein demolition and construction activities are performed concurrently, the project environment is more complex and uncertain. The case study of a large scale renovation project was therefore selected to demonstrate the application of the proposed model.

The case study involved the renovation of the internal layout of Johor Baharu City Square. This landmark was completed in 1998 and consists of a 36 story office building (the tallest building in Johor city), a five story shopping complex and an underground car park. It is a modern, convenient location close to the SingaporeMalaysia customs and immigration checkpoint, with ease of access to public transport, containing more than 200 retailers (local and international brands) and with many food outlets attracting local and international shoppers. The renovation included creating additional lifts, staircases and a new glass roof. The major renovation work was located in the centre of the building associated with structural changes. The slabs, beams and columns of the fifth floor had to be completely removed to create an open space. Most of the shops were to be temporarily closed during the renovation process.

On the other hand, the renovation, maintenance and upgrade of any facility usually involve full or partial service interruptions that result in user dissatisfaction. This issue has several negative impacts on business and can ruin reputations if shoppers are affected. These are the main concerns of every renovation project client, and especially in the case of Johor Baharu City Square, which is an important and iconic Johor State business and tourism attraction.

Ownership of Johor Baharu City Square is shared among the Johor Baharu City Council (MBJB), Johor Baharu Central Municipal Council (MBJBT) and the government of Singapore Investment Corporation (GIC). GIC is the investment arm of the Singapore government that owns $70 \%$ of the shares. The other $30 \%$ of shares are divided between MBJB and MBJBT, with similar responsibilities such as public health and sanitation, waste removal and management, town planning, environmental protection and building control, social and economic development and the general maintenance functions of urban infrastructure but with different coverage areas. The shareholders have their own office of real estate and asset development and the directors of these offices were directly in charge of the renovation of City Square and appointing the project manager and therefore they are effectively the project clients. 
Since the aim is to show how a QFD-CANP model can be used for project manager selection, judgment sampling (a non-probability sampling method) is used (Sekaran, Bougie 2010; Chang et al. 2007; Kang et al. 2011; Lam, Zhao 1998; Lee et al. 2011).

A team of experts was formed comprising one project manager with over 12 years of active experience, holder of MSc degree in construction management and P.M.P certification (E1), one associated processor of civil engineering specialising in demolition with $\mathrm{a} \mathrm{PhD}$ and BEng in civil engineering and MEng in engineering management (E2), and three industrial $\mathrm{PhD}$ students with postgraduate and undergraduate degrees in project management and civil engineering, together with 4, 6 and 6 years of industrial working experience including project management consultancy, safety audition, quality control, environmental monitoring (E3, E4, and E5). Having an in-depth understanding of project management knowledge and relevant working experience were the two main basic criteria for team membership.

\section{Phase I: Decision model}

As discussed in the "Model" section above, ANP decision network of a QFD based project manager selection comprises four levels. Level one represents the decision goal; the overall objective of model and prioritizing decision alternatives. The second level is the main criteria of the decision model (what the clients need). The third level or selection criteria are the way in which the

Table 2. Selection criteria clients' needs are to be answered and final level is the candidates or alternatives.

Three representatives (directors) were individually interviewed. During the interview session they were asked to respond this generic question: "What would you expect from a renovation project manager with respect to characteristics of this project?". Twenty eight vague demands were identified and then summarized. This list was given to the panel of experts and they were asked to first identify and then exclude any similar demands by sorting the demands with the aid of the card sorting technique. Before starting the card sorting session, the panel of experts were briefed on the card sorting technique. In a 90 minute session, the panel of experts grouped the demands into three main categories. Later they were asked to assign a name to each category (translate the vague terms into meaningful criteria). The categories were named time, cost and quality. It is noted that the term quality is a broad term and all environmental, safety and health related demands were sorted under this name. The outcome of this session identified the decision model criteria ( $2^{\text {nd }}$ level of Fig. 3$)$.

Next, the second translation process was started by conducting a focus group discussion in which the team of experts were asked to determine the measures (project manager competency criteria) of clients' time, cost and quality related demands. The outcome of this stage, 18 selection criteria, shown in Table 2 forms the $3^{\text {rd }}$ level of Figure 3. Note that although in broad terms these 18 factors are called selection criteria, they are considered as sub-criteria level in the model.

\begin{tabular}{|c|c|c|}
\hline Selection Criteria & Description & Reference \\
\hline $\begin{array}{l}\text { Job Experience } \\
\text { (JE) }\end{array}$ & $\begin{array}{l}\text { Job experience reviews an applicant's job background that may help the } \\
\text { applicant perform well. Job background may help make the applicant famil- } \\
\text { iar with the working environment and the skills and methods needed to } \\
\text { improve their performance. }\end{array}$ & $\begin{array}{l}\text { Rashidi et al. (2011); Ling and } \\
\text { Loo (2013) }\end{array}$ \\
\hline $\begin{array}{l}\text { Academic } \\
\text { Achievement } \\
\text { (AA) }\end{array}$ & $\begin{array}{l}\text { This can give an overview of applicant's talents and performance and in- } \\
\text { volves reviewing some internal or personal characteristics such as hard- } \\
\text { working, responsible, systematic, and intelligent/knowledge that is im- } \\
\text { portant in reaching the owner's goals. }\end{array}$ & Rashidi et al. (2011) \\
\hline $\begin{array}{l}\text { Communication } \\
\text { Skills } \\
\text { (CS) }\end{array}$ & $\begin{array}{l}\text { A project manager needs to be equipped with effective written and verbal } \\
\text { communication skills. In order for an organization/firm to gain a competi- } \\
\text { tive advantage, managers must strive to increase levels of efficiency, quali- } \\
\text { ty, responsiveness to customers/clients, and innovation. }\end{array}$ & $\begin{array}{l}\text { Rashidi et al. (2011); Goodwin } \\
\text { (1993); Ceran and Dorman } \\
\text { (1995) }\end{array}$ \\
\hline $\begin{array}{l}\text { Microsoft Project } \\
\text { Software } \\
\text { (PMSS) }\end{array}$ & $\begin{array}{l}\text { Increasing complexity and demand for better performance in managing a } \\
\text { project has forced the players in the construction industry to equip them- } \\
\text { selves with effective tools. Planning software allows the project manager to } \\
\text { generate solutions to complex problems using algorithms, modelling, simu- } \\
\text { lations, data processing, and "what-if" analysis. }\end{array}$ & $\begin{array}{l}\text { Goodwin 1993; Ceran and } \\
\text { Dorman (1995); Hegazy et al. } \\
2005\end{array}$ \\
\hline $\begin{array}{l}\text { Planning Skill } \\
\text { (PS) }\end{array}$ & $\begin{array}{l}\text { Planning is an important process used by managers to identify and select } \\
\text { appropriate goals and courses of action for an organization. Planning skill is } \\
\text { needed for scheduling activities in order to achieve a project's goals on } \\
\text { time. }\end{array}$ & $\begin{array}{l}\text { Hwang and Ng (2013); Good- } \\
\text { win (1993); Meredith and Man- } \\
\text { tel (2011); Ceran and Dorman } \\
\text { (1995); Ogunlana et al. (2002) }\end{array}$ \\
\hline $\begin{array}{l}\text { Organizing Skill } \\
\text { (OS) }\end{array}$ & $\begin{array}{l}\text { The project manager creates the structure of working relationships between } \\
\text { organizational members that best allow them to work together and achieve } \\
\text { goals. Good project managers often devise a productive and effective organ- } \\
\text { izational structure. }\end{array}$ & $\begin{array}{l}\text { Hwang and } \mathrm{Ng}(2013) \text {; Mere- } \\
\text { dith and Mantel (2011); Ogun- } \\
\text { lana et al. (2002) }\end{array}$ \\
\hline $\begin{array}{l}\text { Directing/ } \\
\text { Leading } \\
\text { (DL) }\end{array}$ & $\begin{array}{l}\text { In leading, managers determine the project's direction; state a clear vision } \\
\text { for employees to follow, and help employees understand the role they play } \\
\text { in attaining goals. The outcome of the leading function is a high level of } \\
\text { motivation and commitment from employees in the organization. }\end{array}$ & $\begin{array}{l}\text { Goodwin 1993; Ogunlana et al. } \\
\text { (2002) }\end{array}$ \\
\hline
\end{tabular}


Continued Table 2

\begin{tabular}{|c|c|c|}
\hline Selection Criteria & Description & Reference \\
\hline $\begin{array}{l}\text { Controlling/ } \\
\text { Monitoring } \\
\text { (Ctrl) }\end{array}$ & $\begin{array}{l}\text { In controlling, the project manager evaluates how well the organization is } \\
\text { achieving its goals and takes corrective action to improve performance. } \\
\text { Good project manager often monitor individuals, departments and the or- } \\
\text { ganization to determine if the desired level of performance has been } \\
\text { reached. }\end{array}$ & $\begin{array}{l}\text { Hwang and } \mathrm{Ng}(2013) \text {; Mere- } \\
\text { dith and Mantel (2011); Ceran } \\
\text { and Dorman (1995); Ogunlana } \\
\text { et al. (2002) }\end{array}$ \\
\hline $\begin{array}{l}\text { Conducting } \\
\text { Meetings } \\
(\mathrm{CM})\end{array}$ & $\begin{array}{l}\text { This is a basic skill needed for project managers to coordinate their work- } \\
\text { force's knowledge of the current project execution and to discuss any prob- } \\
\text { lems. }\end{array}$ & $\begin{array}{l}\text { Hwang and } \mathrm{Ng}(2013) \text {; Ceran } \\
\text { and Dorman (1995) }\end{array}$ \\
\hline $\begin{array}{l}\text { Record Keeping } \\
(\mathrm{RK})\end{array}$ & $\begin{array}{l}\text { It is necessary to develop a systematic filing system to ease the search for } \\
\text { important documents such as contract documents, plans, daily working } \\
\text { records, purchase orders, submittals, drawings, sketches, letters, transmit- } \\
\text { tals, change order proposals, etc. }\end{array}$ & $\begin{array}{l}\text { Hegazy et al. (2005); Levin } \\
\text { (1998); Hamilton (1991) }\end{array}$ \\
\hline $\begin{array}{l}\text { Time Manage- } \\
\text { ment } \\
\text { (TM) }\end{array}$ & $\begin{array}{l}\text { Project managers need to maintain a meaningful schedule to monitor the } \\
\text { contractor's work progress and to use as a tool in resolving disputes caused } \\
\text { by delays and acceleration. Multi-tasking is important to same time. Time } \\
\text { management is also important because a primary objective of construction } \\
\text { work is to minimize time and cost while maintaining project quality. }\end{array}$ & $\begin{array}{l}\text { Hwang and } \mathrm{Ng}(2013) \text {; Yasin } \\
\text { et al. (2002) }\end{array}$ \\
\hline $\begin{array}{l}\text { Property } \\
\text { Management } \\
(\mathrm{PM})\end{array}$ & $\begin{array}{l}\text { Property management refers to the performance of the ongoing maintenance } \\
\text { or repair of a construction project after the completion of the construction } \\
\text { phase. }\end{array}$ & $\begin{array}{l}\text { Arditi and Nawakorawit } \\
\text { (1999); Horner et al. (1997); } \\
\text { Chanter and Swallow (2007) }\end{array}$ \\
\hline $\begin{array}{l}\text { Worker welfare } \\
\text { Management } \\
(\text { WWM) }\end{array}$ & $\begin{array}{l}\text { The project manager needs to make sure that workers' welfare is considered } \\
\text { in order to engender a harmonious working atmosphere and take action to } \\
\text { protect workers being injured during construction. They have to bear in } \\
\text { mind, that workers and employees are the main asset in their project. }\end{array}$ & $\begin{array}{l}\text { Ogunlana et al. (2002); Hwang } \\
\text { and Ng (2013); Roethlisberger } \\
\text { and Dickson (2003); Ofori } \\
\text { et al. (2004) }\end{array}$ \\
\hline $\begin{array}{l}\text { Rules and } \\
\text { Regulation } \\
\text { (RR) }\end{array}$ & $\begin{array}{l}\text { It is necessary for a project manager to have a wide knowledge of law and } \\
\text { contract regulations. It is important to be familiar with standard construction } \\
\text { practice and methods and keep abreast of new developments and changes in } \\
\text { the field. The project manager needs to know the rules in pertaining to a } \\
\text { contract including the contract clauses, Occupational Safety and Health Act } \\
\text { (OSHA) regulations and Code of Conduct. }\end{array}$ & $\begin{array}{l}\text { Yasin et al. (2002); Czuchry } \\
\text { and Yasin (2003) }\end{array}$ \\
\hline $\begin{array}{l}\text { Problem Solving } \\
\text { Skills } \\
\text { (PSS) }\end{array}$ & $\begin{array}{l}\text { The most common issues related to construction projects are those originat- } \\
\text { ing from delays, suspension, or acceleration of the times established in the } \\
\text { contract for the completion of work. Site conditions may present as a prob- } \\
\text { lem, especially subsurface conditions. }\end{array}$ & $\begin{array}{l}\text { Hwang and } \mathrm{Ng}(2013) \text {; Mere- } \\
\text { dith and Mantel (2011); Ogun- } \\
\text { lana et al. (2002); Prieto (2013) }\end{array}$ \\
\hline $\begin{array}{l}\text { Decision Making } \\
\text { (DM) }\end{array}$ & $\begin{array}{l}\text { Decision making is a process by which managers respond to opportunities } \\
\text { and threats by analysing options, and making decision concerning goals and } \\
\text { courses of action. }\end{array}$ & $\begin{array}{l}\text { Hwang and } \mathrm{Ng}(2013) \text {; Ogun- } \\
\text { lana et al. (2002); Ling and } \\
\text { Loo (2013) }\end{array}$ \\
\hline $\begin{array}{l}\text { Multi-Tasking } \\
\text { (MT) }\end{array}$ & $\begin{array}{l}\text { If the project manager cannot handle the volume of work involved, this is } \\
\text { likely to lead to submittal delays, scheduling conflicts, and a negative im- } \\
\text { pact on the project. Ability to multi-task is therefore a useful skill to have. }\end{array}$ & Keil et al. (2013) \\
\hline $\begin{array}{l}\text { Correspondence } \\
\text { (Crp) }\end{array}$ & $\begin{array}{l}\text { Correspondence means communication through sharing of information } \\
\text { between two or more individuals and groups. Effective communication can } \\
\text { lead to high efficiency. }\end{array}$ & $\begin{array}{l}\text { Cassin (2003); Tian and Peng } \\
\text { (2010); Senescu et al. (2014) }\end{array}$ \\
\hline
\end{tabular}

The ISM methodology was then applied. The five experts were asked to identify the existing relationships between the decision elements in the criteria and subcriteria levels, with questions similar to those in Section "Interpretive Structural Modelling (ISM)". After collecting the answers for every two variables, they were checked to see which had reached a consensus, with the judgments being regarded as acceptable if the consensus was made. The iterative process of consensus forming continued until the majority of the experts agreed on the judgments. Once the process stopped, the contextual relationship matrices of $A_{1}$ and $A_{2}$ were formed. The two matrices were then checked for transitivity. The transitive reachable matrix $\left(W_{r 4}\right.$ and $\left.W_{r 2}\right)$ for each contextual relationship matrix was obtained when the formula (1) was applied:

$$
\begin{aligned}
& W_{r 2}=\left(A_{2}+I\right)^{3}=\left(A_{2}+I\right)^{2} ; \\
& W_{r 4}=\left(A_{1}+I\right)^{3}=\left(A_{1}+I\right)^{2},
\end{aligned}
$$

where: $A_{1}$ and $A_{2}$ denote as contextual relationship in the second and third level of decision model and $I$ is the identity matrix, $W_{r 2}$ and $W_{r 4}$ are the reachability matrix and represents the final relationship between the decision variables. $W_{r 2}$ and $W_{r 4}$ are respectively denoted by:

$\begin{array}{cccc} & \text { Time } & \text { Cost } & \text { Quality } \\ \text { Time } & 1 & 1 & 1 \\ \text { Cost } & 1 & 1 & 1 \\ \text { Quality } & 1 & 1 & 1\end{array}$


Continued Table 3

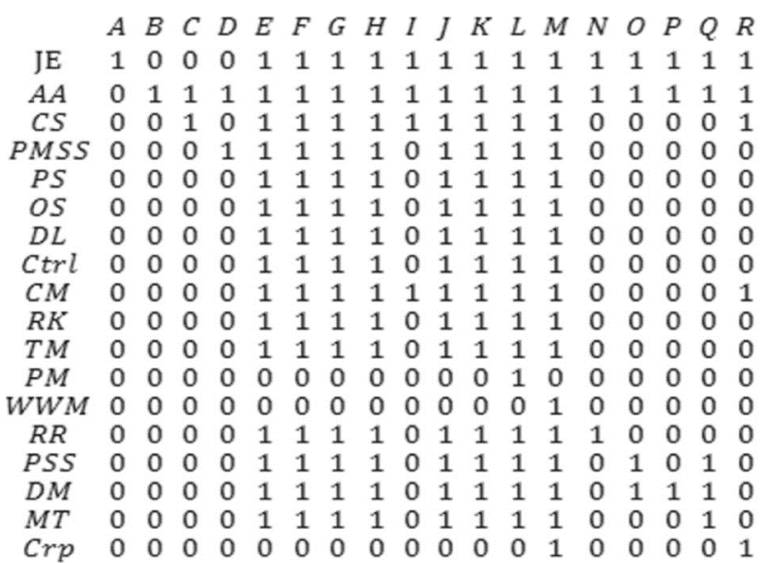

where $A, B, C, \ldots, R$ respectively represent $J E, A A$, $C S, \ldots$, Crp.

The transitive reachable matrices resemble a road map in guiding the relationship diagram to be drawn. Table 3 and Figure 2 show how the transitive matrix $W_{r 2}$ and $W_{r 4}$ are converted to ANP network of interactions.

Thereafter, applicants were invited for the renovation project manager position. To be eligible, applicants needed to satisfy three basic requirements: experience with demolition projects either as a project manager or site manager; an academic degree related to the job; and having demolition training certification. Six eligible applicants were invited to an interview session.

Table 3. Interactions in the sub-criteria level

\begin{tabular}{|c|c|c|c|c|c|c|c|c|c|}
\hline & $J E$ & $\boldsymbol{A} \boldsymbol{A}$ & $C S$ & PMSS & $P S$ & os & $D L$ & Ctrl & $C M$ \\
\hline$J E$ & $\downarrow$ & & & & $\downarrow$ & $\downarrow$ & $\downarrow$ & $\downarrow$ & $\downarrow$ \\
\hline$A A$ & & $\downarrow$ & $\downarrow$ & $\downarrow$ & $\downarrow$ & $\downarrow$ & $\downarrow$ & $\downarrow$ & $\downarrow$ \\
\hline CS & & & $\downarrow$ & & $\downarrow$ & $\downarrow$ & $\downarrow$ & $\downarrow$ & $\downarrow$ \\
\hline PMSS & & & & $\downarrow$ & $\downarrow$ & $\downarrow$ & $\downarrow$ & $\downarrow$ & \\
\hline$P S$ & & & & & $\downarrow$ & $\downarrow$ & $\downarrow$ & $\downarrow$ & \\
\hline$O S$ & & & & & $\downarrow$ & $\downarrow$ & $\downarrow$ & $\downarrow$ & \\
\hline$D L$ & & & & & $\downarrow$ & $\downarrow$ & $\downarrow$ & $\downarrow$ & \\
\hline Ctrl & & & & & $\downarrow$ & $\downarrow$ & $\downarrow$ & $\downarrow$ & \\
\hline$C M$ & & & & & $\downarrow$ & $\downarrow$ & $\downarrow$ & $\downarrow$ & $\downarrow$ \\
\hline$R K$ & & & & & $\downarrow$ & $\downarrow$ & $\downarrow$ & $\downarrow$ & \\
\hline$T M$ & & & & & $\downarrow$ & $\downarrow$ & $\downarrow$ & $\downarrow$ & \\
\hline$P M$ & & & & & & & & & \\
\hline$W W M$ & & & & & & & & & \\
\hline$R R$ & & & & & $\downarrow$ & $\downarrow$ & $\downarrow$ & $\downarrow$ & \\
\hline PSS & & & & & $\downarrow$ & $\downarrow$ & $\downarrow$ & $\downarrow$ & \\
\hline$D M$ & & & & & $\downarrow$ & $\downarrow$ & $\downarrow$ & $\downarrow$ & \\
\hline$M T$ & & & & & $\downarrow$ & $\downarrow$ & $\downarrow$ & $\downarrow$ & \\
\hline Crp & & & & & & & & & \\
\hline
\end{tabular}

\begin{tabular}{|r|ccccccccc|}
\hline & $\boldsymbol{R K}$ & $\boldsymbol{T M}$ & $\boldsymbol{P M}$ & $\boldsymbol{W W M}$ & $\boldsymbol{R R}$ & $\boldsymbol{P S S}$ & DM & MT & Crp \\
\hline JE & $\downarrow$ & $\downarrow$ & $\downarrow$ & $\downarrow$ & $\downarrow$ & $\downarrow$ & $\downarrow$ & $\downarrow$ & $\downarrow$ \\
CS & $\downarrow$ & $\downarrow$ & $\downarrow$ & $\downarrow$ & $\downarrow$ & $\downarrow$ & $\downarrow$ & $\downarrow$ & $\downarrow$ \\
$P M S S$ & $\downarrow$ & $\downarrow$ & $\downarrow$ & $\downarrow$ & & & & & $\downarrow$ \\
$P S$ & $\downarrow$ & $\downarrow$ & $\downarrow$ & $\downarrow$ & & & & & \\
$O S$ & $\downarrow$ & $\downarrow$ & $\downarrow$ & $\downarrow$ & & & & & \\
$D L$ & $\downarrow$ & $\downarrow$ & $\downarrow$ & $\downarrow$ & & & & & \\
$C t r l$ & $\downarrow$ & $\downarrow$ & $\downarrow$ & $\downarrow$ & & & & & \\
$C M$ & $\downarrow$ & $\downarrow$ & $\downarrow$ & $\downarrow$ & & & & & $\downarrow$ \\
$R K$ & $\downarrow$ & $\downarrow$ & $\downarrow$ & $\downarrow$ & & & & & \\
$T M$ & $\downarrow$ & $\downarrow$ & $\downarrow$ & $\downarrow$ & & & & & \\
$P M$ & & & $\downarrow$ & & & & & & \\
$W W M$ & & & & $\downarrow$ & & & & & \\
$R R$ & $\downarrow$ & $\downarrow$ & $\downarrow$ & $\downarrow$ & $\downarrow$ & & & & \\
$P S S$ & $\downarrow$ & $\downarrow$ & $\downarrow$ & $\downarrow$ & & $\downarrow$ & & $\downarrow$ & \\
$D M$ & $\downarrow$ & $\downarrow$ & $\downarrow$ & $\downarrow$ & & $\downarrow$ & $\downarrow$ & $\downarrow$ & \\
$M T$ & $\downarrow$ & $\downarrow$ & $\downarrow$ & $\downarrow$ & & & & $\downarrow$ & \\
$C r p$ & & & & $\downarrow$ & & & & & $\downarrow$ \\
\hline
\end{tabular}

Figure 2 illustrates the decomposition of the decision problem into a model with three main criteria, eighteen sub-criteria and six alternatives.

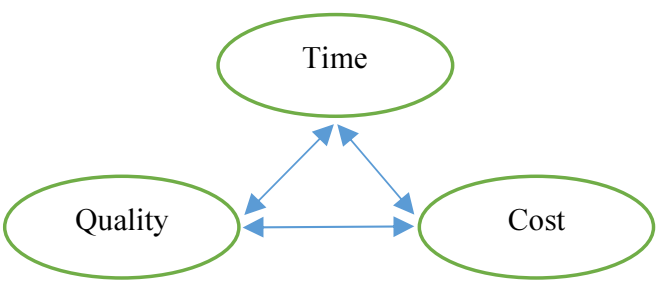

Fig. 2. Depicted network of interactions based on $W_{r 2}$ in the criteria level

\section{Phase II: Knowledge acquisition}

The decision network depicted in Phase I (Fig. 3) indicates how the knowledge of the experts under the framework of CANP should be elicited in order to satisfy the two main objectives of prioritizing selection criteria and evaluating candidates against weighted criteria. In order to achieve the first objective, three sets of questionnaires were designed to acquire knowledge concerning two different target individuals; the client team's representatives and the panel of experts. The decision criteria (time, cost and quality) are the translation of client vague demands into meaningful needs. Hence, it is necessary for the client team's representatives to prioritize their needs. The first questionnaire, following the cybernetic ANP framework, was given to client team and they were asked to answer this generic question: "On the scale of 1-9 rank time, cost and quality according to your preference". 


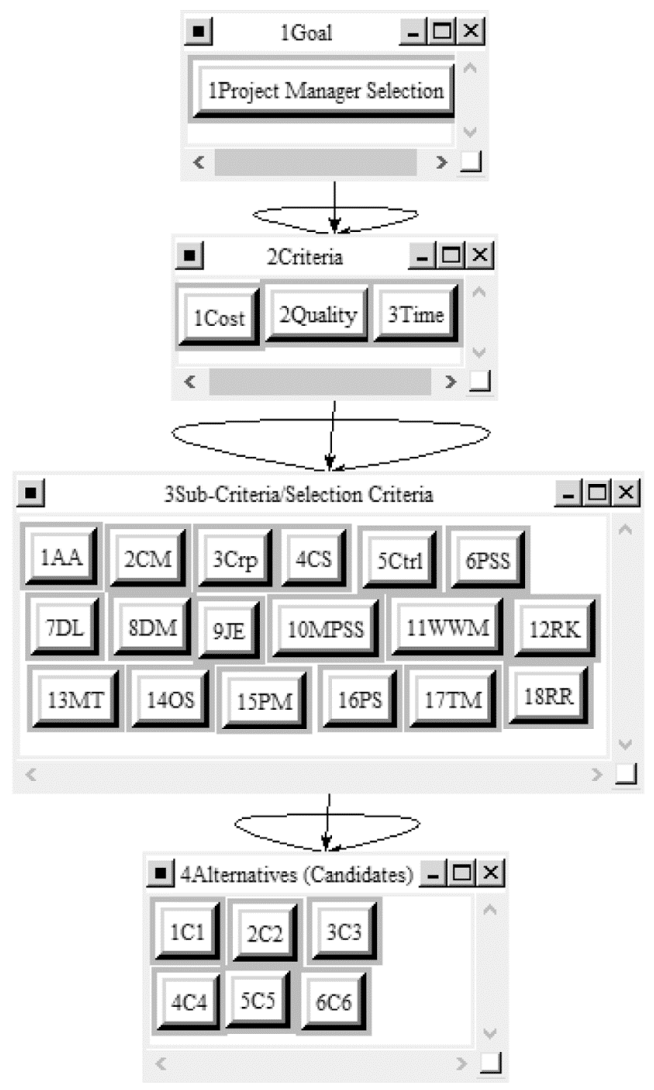

Fig. 3. ANP decision network of project manager selection

Thereafter, the second set of questionnaires was given to experts in order to identify the degree to which the selection criteria were able to satisfy the client's needs, since the client team are not sufficiently well informed to judge on this issue. At this stage, the expert panel was asked to respond the question: "Assume the 18 selection criteria are on the table, on a scale of 1 (not important) to 9 (extremely important) rank the degree to which these 18 criteria are able to satisfy the client's time demands". This survey was repeated for quality and cost because the elements of sub-criteria level were connected to all three time, cost and quality criteria.

The final set of questionnaires following the road map shown in Table 3 and Figure 2 was designed to measure the degree to which criteria and sub-criteria correlate to each other $\left(W_{2}, W_{4}\right)$. This type of question was asked: "Given the control criterion $C r p$, which one of the $C M, A A$, $C S$ and $J E$ is more helpful in achieving Crp? Assume that $C M, A A, C S$ and $J E$ are on the table, on the scale of 1-9 rate these factors according to their degree of influence".

The second objective was achieved through conducting structured interviews with the six applicants. This involved a set of open-ended questions carefully designed to match the selection criteria. During a 25 minutes interview session with each candidate, they were asked to answer this type of question: "How much the ability to use project planning software helps project manager and how do you describe yourself in this regard?" (question matched with MPSS criterion). The experts were asked to evaluate the candidates based on the given answers on the scale of 1 (not qualified) to 9 (extremely qualified). $1^{\text {st }}$ Level

Goal

$2^{\text {nd }}$ Level

Interview with representatives

Card Sorting (Panel of Expert)

ISM (Panel of Expert)

Cybernetic pairwise comparison

$3^{\text {rd }}$ Level

Interview

Focus Group Discussion (Panel of Expert)

ISM (Panel of Expert)

Cybernetic pairwise comparisons $4^{\text {th }}$ Level

Call for Project manager position

Screening (Panel of Expert)

Interview with open-ended question (Panel of Expert)

Cybernetic pairwise comparisons

To show how the calculations under CANP are performed, $C r p$ was selected as a control criterion. Initially, as shown in Table 4, the five experts were asked to score all four selection criteria correlated with Crp. With the aid of Pair-Wiser rules, the given scores were then translated into pairwise comparisons. The aggregated pairwise comparison matrix of the five experts obtained is shown in Table 5. Next, Eqn (2) was applied to estimate the relative importance of each of the ten selection criteria. The influence of Crp on each selection criteria was then estimated by solving this equation. Finally, CR $=0.00029$ as measure for consistency of judgment was computed. Since the value was less than $10 \%$, the estimated priority vectors for $A A, C M, C S$ and $J E$ were considered to be acceptable (Table 6).

The above process should be repeated for all control criteria. After estimation of all the priority vectors, the normalized vectors were transferred to the corresponding cells of supermatrix $\mathrm{W}$ in order to create the unweighted supermatrix. The column stochastic matrix was computed and as explained earlier, raised to $15^{\text {th }}$ power where the steady limit supermatrix was obtained. The 15 matrices

Table 4. Pair-wiser scoring

\begin{tabular}{lccccc}
\hline \multirow{2}{*}{ With Respect to Correspondence } & \multicolumn{5}{c}{ Pair-wiser Scoring } \\
\cline { 2 - 6 } & E1 & E2 & E3 & E4 & E5 \\
\hline Academic Achievement & 6 & 5 & 4 & 6 & 5 \\
\hline Communication Skill & 8 & 9 & 6 & 5 & 7 \\
\hline Job Experience & 8 & 9 & 8 & 7 & 6 \\
\hline Conduct meeting & 7 & 5 & 7 & 7 & 8 \\
\hline
\end{tabular}


Table 5. Transformation of Pair-wiser to group pairwise comparison

\begin{tabular}{ccccccc}
\hline \multirow{2}{*}{ With Respect to Crp } & \multicolumn{7}{c}{$C M$} \\
\cline { 2 - 7 } & E1 & E2 & E3 & E4 & E5 & GM \\
\hline$A A$ & $1 / 2$ & 1 & $1 / 4$ & $1 / 2$ & $1 / 4$ & 0.44 \\
\hline \multirow{2}{*}{ With Respect to Crp } & \multicolumn{7}{c}{ CS } \\
\cline { 2 - 7 } & E1 & E2 & E3 & E4 & E5 & GM \\
\hline$A A$ & $1 / 3$ & $1 / 5$ & $1 / 3$ & 2 & $1 / 3$ & 0.43 \\
\hline$C M$ & $1 / 2$ & $1 / 5$ & 2 & 3 & 2 & 1 \\
\hline \multirow{2}{*}{ With Respect to Crp } & & & & $J E$ & & \\
\cline { 2 - 7 } & $\mathrm{E} 1$ & $\mathrm{E} 2$ & $\mathrm{E} 3$ & $\mathrm{E} 4$ & $\mathrm{E} 5$ & $\mathrm{GM}$ \\
\hline$A A$ & $1 / 3$ & $1 / 5$ & $1 / 5$ & $1 / 2$ & $1 / 2$ & 0.32 \\
\hline$C M$ & $1 / 2$ & $1 / 5$ & $1 / 2$ & 1 & 3 & 0.68 \\
\hline$C S$ & 1 & 1 & $1 / 3$ & $1 / 3$ & 2 & 0.74 \\
\hline
\end{tabular}

Table 6. Weight vectors

\begin{tabular}{|c|c|c|c|}
\hline Name & Normalized & Idealized & ১ ট্త \\
\hline$A A$ & 0.1144097 & 0.314159 & एँ हे \\
\hline$C M$ & 0.2572197 & 0.706303 & 8 \\
\hline$C S$ & 0.2641928 & 0.72545 & 0 \\
\hline$J E$ & 0.3641778 & 1 & $\Xi$ \\
\hline
\end{tabular}

were summed and then renormalized to obtain the final limit supermatrix where the priorities of the 27 elements with respect to the overall goal were obtained (Table 7).

\section{Validation of the model}

There are many strategies suggested by scholars to validate a study. Fuertes et al. (2013) examined the comprehensiveness, reliability, suitability and diagnosticity of their model in order to test content, face and construct validity. The authors argue that construction management related models are costly to validate since they need a large amount of data or multiple implementation. Statistical analysis is a fundamental necessity behind their pro- posed validation strategy along with measurement of the experts' degree of agreement with the results. Another widely used validation strategy is to compare the output of the model with that of existing models (Gibb et al. 2006; Juan et al. 2009; Sun, Meng 2009).

The second strategy was adopted to validate the model and the Serbian VIseKriterijumska Optimizacija I Kompromisno Resenje (VIKOR) method was selected to rank candidates and the final results were compared with the rank order derived by the QFD-CANP project manager selection model. VIKOR is a Multiple Criteria Decision Making (MCDM) tool that is used to rank alternatives (Opricovic, Tzeng 2004). The ranking results are based on the closeness to an ideal solution. This technique is usually incorporated with other MCDM techniques such as AHP/ANP or Delphi method since the criteria of the decision model should be weighted first. The project manager selection criteria had already been weighted with the aid of CANP. Hence, the same priorities were used. The steps according to Büyüközkan and Ruan (2008), Tavakkoli-Moghaddam et al. (2011) to find the most competent candidate were:

Step 1. A team of experts were formed. The same panel of experts were used since their experience and knowledge helps to generate more reliable results;

Step 2. The experts were weighted based on their experience and knowledge. This is because different experts have different level of expertise and knowledge. A simple individual AHP-based decision model was developed where knowledge and experience represent decision criteria and five panel members represent alternatives. The criteria with respect to goal and alternatives with respect to each criterion were pairwise compared in order to determine the weighting of each expert. Table 8 shows the results.

Table 7. Overall priorities of client needs, project manager selection criteria and candidates

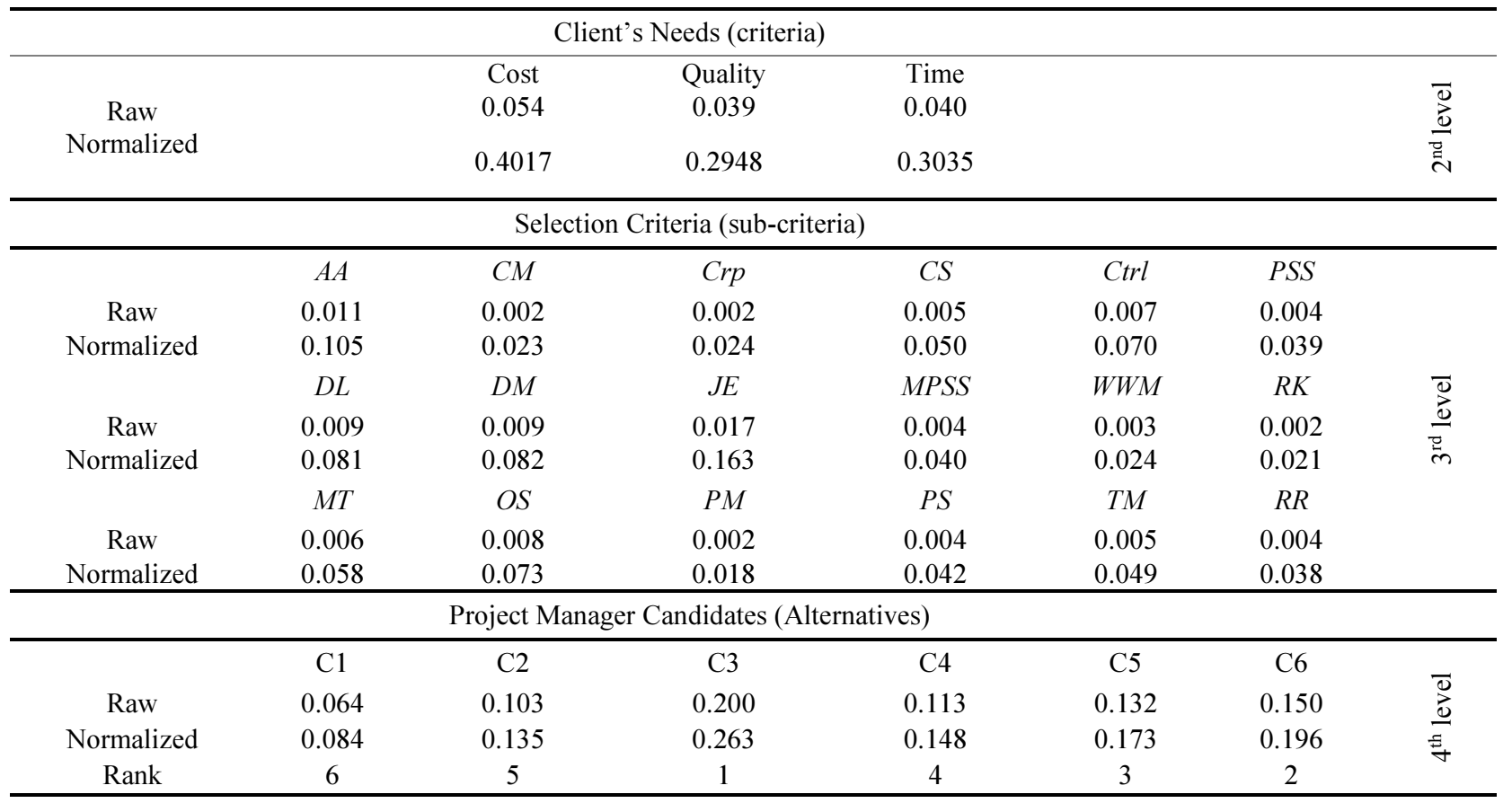


Table 8. Expert's weights

\begin{tabular}{clc}
\hline & Nodes & Weights \\
\hline \multirow{2}{*}{ Criteria } & Knowledge (E1) & 0.364 \\
& Experience (E2) & 0.636 \\
\hline \multirow{4}{*}{ Alternatives } & Project Manager (E3) & $\mathbf{0 . 2 2 0}$ \\
& Associated Professor (E4) & $\mathbf{0 . 2 8 2}$ \\
& Industrial PhD Student (E5) & $\mathbf{0 . 1 6 1}$ \\
& Industrial PhD Student (E6) & $\mathbf{0 . 1 6 4}$ \\
& Industrial PhD Student (E7) & $\mathbf{0 . 1 7 3}$ \\
\hline
\end{tabular}

Step 3. The panel of experts were asked to evaluate the project manager candidates with respect to each criterion (structured interview) and score them based on a five point Likert's scale;

Step 4. For each evaluation the deviation between weighted arithmetic mean (3) of five experts and each expert's judgment should be no greater than 0.2 :

$$
\begin{aligned}
& f_{i j}= \\
& \frac{0.22 *_{s_{i j 1} 1}+0.282 *{ }_{s i j 2}+0.161^{*}{ }_{s i j 3}+0.164 *_{s i j 4}+0.173 * s_{i j 5}}{0.22+0.282+0.161+0.164+0.173}
\end{aligned}
$$

Step 5. In cases where the deviation (d) was greater than 0.2 the relevant expert was notified to revise his judgment and iteration started from (3) until two successive weighted averages became very close to each other $(\mathrm{d} \leq 0.2)$;

Step 6. Apply the VIKOR mathematics. This involves:

(a) Determining the best and the worst weighted average value under each criterion $\left(f_{i}^{+}, f_{i}^{-}\right)$by applying Eqn (4):

$$
f_{i}^{+}=\operatorname{Max}_{j} f_{i j}, f_{i}^{-}=\operatorname{Max}_{j} f_{i j} ;
$$

(b) Computing $S_{j}$ (separation measure of the $i^{\text {th }}$ alternative from the best value with respect to all criteria), $R_{j}$ (separation measure of the $i^{\text {th }}$ alternative from the worst value with respect to all criteria) and $Q_{j}$ (VIKOR index) by applying Eqns (5), (6) and (7) where $w_{j}$ is the normalized weight of criterion $j$ and $v=0.5$ :

$$
\begin{gathered}
R_{j}=\max _{j}\left[w_{j} \frac{\left(f_{j}^{+}-f_{i j}\right)}{\left(f_{j}^{+}-f_{i}^{-}\right)}\right], R_{j} \in[0,1] \\
S_{j}=\sum_{i=1}^{n} w_{j} \frac{\left(f_{j}^{+}-f_{i j}\right)}{\left(f_{j}^{+}-f_{i}^{-}\right)}, S_{j} \in[0,1] \\
Q_{j}=\frac{v\left(S_{j}-S^{+}\right)}{\left(S^{-}-S^{+}\right)}+\frac{(1-v)\left(R_{j}-R^{+}\right)}{R^{-}-R^{+}}
\end{gathered}
$$

where: $\quad S^{+}=\min _{j} S_{j}, \quad S^{-}=\max _{j} S_{j}$ and $R^{+}=\min _{j} R_{j}, R^{-}=\max _{j} R_{j} ;$

(c) Proposing a compromise solution: Sort the alternatives into descending value order based on $S_{j}, R_{j}$ and
$Q_{j}$. Alternative $A^{\prime}$ (the alternative with the lowest value of $Q_{j}$ ) is proposed as a compromise solution if both $\mathrm{C}_{1}$ and $\mathrm{C}_{2}$ are satisfied:

$$
\mathrm{C}_{1} \text {. "Acceptable Advantage" if } Q\left(A^{\prime \prime}\right)-Q\left(A^{\prime}\right) \geq
$$
$\frac{1}{m-1} \ldots$, where $m=$ number of alternatives and $A^{\prime \prime}$ is the alternative with second lowest $Q j$.

$\mathrm{C}_{2}$. "Acceptable Stability" if alternative $\left(A^{\prime}\right)$ is the best in the $R_{j}$ and/or $S_{j}$ ranking.

A set of compromise solutions is proposed if one of the above conditions is not satisfied. If $\mathrm{C}_{2}$ fails then the compromise solution is $\left\{A^{\prime}\right.$ and $\left.A^{\prime \prime}\right\}$ or if $\mathrm{C}_{2}$ fails then the compromise solution is $\left\{A^{\prime}, A^{\prime \prime} \ldots A^{m}\right\}$ and $A^{m}$ is determined by $Q\left(A^{m}\right)-Q\left(A^{\prime}\right)<\frac{1}{m-1}$ for maximum $(m)$. The propositions of these alternatives are "in closeness". Table 9 shows the candidates' ranking according to the $S$, $R$ and $Q$ index in decreasing order. The minimum amount of $Q$ index belongs to the second candidate and since $Q(\mathrm{C} 2)-Q(\mathrm{C} 1)=0.572>0.2$ the first condition is sa-

\begin{tabular}{|c|c|c|c|c|c|c|}
\hline \multicolumn{7}{|c|}{ Criteria } \\
\hline & $J E$ & $A A$ & $C S$ & PMSS & $P S$ & OS \\
\hline & 0.196 & 0.176 & 0.049 & 0.037 & 0.043 & 0.052 \\
\hline$C l$ & 0.196 & 0.176 & 0.041 & 0.037 & 0.037 & 0.026 \\
\hline$C 2$ & 0.172 & 0.106 & 0.008 & 0.021 & 0.018 & 0.052 \\
\hline$C 3$ & 0.049 & 0.000 & 0.016 & 0.011 & 0.000 & 0.000 \\
\hline$C 4$ & 0.098 & 0.141 & 0.049 & 0.037 & 0.043 & 0.035 \\
\hline$C 5$ & 0.172 & 0.000 & 0.000 & 0.021 & 0.024 & 0.043 \\
\hline \multirow[t]{3}{*}{ C6 } & 0.000 & 0.141 & 0.033 & 0.000 & 0.043 & 0.035 \\
\hline & $D L$ & Ctrl & $C M$ & $R K$ & $T M$ & $P M$ \\
\hline & 0.061 & 0.055 & 0.023 & 0.021 & 0.037 & 0.011 \\
\hline$C 1$ & 0.061 & 0.055 & 0.023 & 0.021 & 0.037 & 0.011 \\
\hline$C 2$ & 0.026 & 0.027 & 0.015 & 0.008 & 0.022 & 0.004 \\
\hline$C 3$ & 0.000 & 0.000 & 0.003 & 0.000 & 0.007 & 0.000 \\
\hline$C 4$ & 0.044 & 0.055 & 0.006 & 0.017 & 0.030 & 0.009 \\
\hline$C 5$ & 0.026 & 0.009 & 0.021 & 0.000 & 0.000 & 0.011 \\
\hline \multirow[t]{3}{*}{ C6 } & 0.018 & 0.045 & 0.000 & 0.017 & 0.030 & 0.009 \\
\hline & $W W M$ & $R R$ & PSS & $D M$ & $M T$ & Crp \\
\hline & 0.014 & 0.036 & 0.037 & 0.087 & 0.051 & 0.014 \\
\hline$C l$ & 0.014 & 0.036 & 0.037 & 0.069 & 0.000 & 0.000 \\
\hline$C 2$ & 0.012 & 0.022 & 0.021 & 0.035 & 0.051 & 0.014 \\
\hline C3 & 0.009 & 0.007 & 0.010 & 0.000 & 0.029 & 0.009 \\
\hline C4 & 0.005 & 0.007 & 0.000 & 0.069 & 0.015 & 0.002 \\
\hline$C 5$ & 0.002 & 0.000 & 0.026 & 0.035 & 0.036 & 0.013 \\
\hline \multirow[t]{3}{*}{ C6 } & 0.000 & 0.022 & 0.016 & 0.087 & 0.029 & 0.005 \\
\hline & \multicolumn{6}{|c|}{ Ranking of project manager candidates } \\
\hline & $C 5$ & $\mathrm{Cl}$ & $C 4$ & $C 3$ & C6 & $C 2$ \\
\hline S Value & 0.439 & 0.877 & 0.660 & 0.151 & 0.528 & 0.635 \\
\hline$R$ Value & 0.172 & 0.196 & 0.141 & 0.049 & 0.141 & 0.172 \\
\hline$Q$ Index & 0.615 & 1.000 & 0.663 & 0.000 & 0.572 & 0.750 \\
\hline Ranking & 3 & 6 & 4 & 1 & 2 & 5 \\
\hline
\end{tabular}
tisfied. In addition, the second candidate also has the best situation according to the $S$ and $R$ values and therefore the "acceptable stability" conditions have been also satisfied.

Table 9. Evaluation of alternatives with respect to criteria (integrated) and the VIKOR index 
Comparison of candidates' ranking in both Table 7 and 9 indicates that the VIKOR ranking results are similar to the QFD-CANP rank order $(\mathrm{C} 3>\mathrm{C} 6>\mathrm{C} 5>\mathrm{C} 4>$ $\mathrm{C} 2>\mathrm{C} 1)$. This similarity of results supports the validity of proposed model. Note that, due to the inability of VIKOR to prioritize client's needs and selection criteria, adding another decision-making technique to prioritize decision criteria and sub-criteria adds more complexity to the process. In contrast, the strong mathematics behind ANP is able to prioritize the client's needs, selection criteria and alternatives of the decision model, which lessens the computations and facilitates the quantification of the two stages of the QFD process if real experts make consistent judgments.

\section{Conclusions and recommendations}

Decision making for selection has always involved complexity and uncertainty especially when the decision maker deals with large number of decision criteria and alternatives. Project manager selection also has a complex and uncertain environment wherein the decision maker evaluates several candidates against a series of selection criteria. The more criteria and alternatives, the higher the risk of misjudgment, especially when the decision maker relies on unstructured decision making methods. In the renovation and refurbishment business, where the environment is more technical and dynamic compared with construction because of the simultaneous operation of construction and demolition activities, there is a need for appropriate decision making in the selection of a project manager - who will have considerable and crucial responsibilities for all aspects of project. With the aid of a quality management tool this paper first identifies what project clients need (WHATs) and then determines what specialities project manager should have in order to satisfy these needs (HOWs). A decision problem comprising four levels including goal, criteria, sub-criteria and alternatives is formulated and a multiple criteria decision making tool developed with the ability to take into account inter and inner-dependencies.

The contribution of this paper is creation of a twostage QFD based decision making model that, with the aid of CANP, is able to select the most competent candidate in a structured way with less judgments and a stressfree complex computation process. In contrast with common project manager selection methods in which the selection of candidates is based solely on matching project manager competency criteria, this study highlights the direct influence of client demands (what the unique characteristics of the project imply) on selection criteria that indirectly influence the candidates' ranking. It is also concluded that correlation in criteria and sub-criteria level should be accommodated since this helps to obtain more reliable and actualized prioritisation of selection criteria.

A limitation of the model is not taking into account the subjectivity of judgments during deployment of QFD and acquisition of knowledge either in ISM or CANP. Future research is needed to incorporate fuzzy set theories to handle the associated subjectivity. More case studies are also needed to further develop the database of client de- mands so that more project characteristics are identified and the QFD's translation process to the database of refurbishment project manager competency criteria.

\section{Acknowledgements}

This research was financially supported by the Universiti Teknologi Malaysia (GUP reference number PY/2012/00304), Graduate University of Advanced Technology of Kerman and a scholarship offered by Islamic Azad University, Fouman and Shaft Branch. The authors would like to express their gratitude to the above mentioned universities for the assistance and support provided during the time of research.

\section{References}

Abastante, F.; Lami, I. M. 2012. Quality function deployment (QFD) and analytic network process (ANP): an application to analyze a cohousing intervention, Journal of Applied Operational Research 4(1): 14-27.

Afshari, A. R.; Yusuff, R.; Derayatifar, A. R. 2012. Project manager selection by using Fuzzy Simple Additive Weighting method, in 2012 International Conference on Innovation Management and Technology Research (ICIMTR), 21-22 May 2012, Malacca, 412-416.

Akao, Y. 1972. New product development and quality assurance - quality deployment system, Standardization and Quality Control 25(4): 7-14.

Arditi, D.; Nawakorawit, M. 1999. Issues in building maintenance: property managers' perspective, Journal of Architectural Engineering 5(4): 117-132.

http://dx.doi.org/10.1061/(ASCE)10760431(1999)5:4(117)

Asan, U.; Soyer, A.; Serdarasan, S. 2012. A fuzzy analytic network process approach, in C. Kahraman (Ed.). Computational intelligence systems in industrial engineering. Atlantis Press, 155-179.

Azevedo, S.; Carvalho, H.; Cruz-Machado, V. 2013. Using interpretive structural modelling to identify and rank performance measures: an application in the automotive supply chain, Baltic Journal of Management 8(2): 208230. http://dx.doi.org/10.1108/17465261311310027

Bevilacqua, M.; Ciarapica, F.; Giacchetta, G. 2006. A fuzzyQFD approach to supplier selection, Journal of Purchasing and Supply Management 12(1): 14-27. http://dx.doi.org/10.1016/j.pursup.2006.02.001

Bhattacharya, A.; Sarkar, B.; Mukherjee, S. K. 2005. Integrating AHP with QFD for robot selection under requirement perspective, International Journal of Production Research 43(17): 3671-3685. http://dx.doi.org/10.1080/00207540500137217

Büyüközkan, G.; Ruan, D. 2008. Evaluation of software development projects using a fuzzy multi-criteria decision approach, Mathematics and Computers in Simulation 77(5): 464-475. http://dx.doi.org/10.1016/j.matcom.2007.11.015

Cassin, R. 2003. Leadership and communications in civil engineering: past, present and future, Leadership and Management in Engineering 3(3): 145-147. http://dx.doi.org/10.1061/(ASCE)15326748(2003)3:3(145)

Ceran, T.; Dorman, A. 1995. The complete project manager, Journal of Architectural Engineering 1(2): 67-72. http://dx.doi.org/10.1061/(ASCE)10760431(1995)1:2(67) 
Chandramowli, S.; Transue, M.; Felder, F. A. 2011. Analysis of barriers to development in landfill communities using interpretive structural modeling, Habitat International 35(2): 246-253.

http://dx.doi.org/10.1016/j.habitatint.2010.09.005

Chang, C.; Wu, C.; Lin, C.; Chen, H. 2007. An application of AHP and sensitivity analysis for selecting the best slicing machine, Computers \& Industrial Engineering 52(2): 296-307. http://dx.doi.org/10.1016/j.cie.2006.11.006

Chanter, B.; Swallow, P. 2007. Building maintenance management. $2^{\text {nd }}$ ed. Oxford: Blackwell. $332 \mathrm{p}$. http://dx.doi.org/10.1002/9780470692011

Chen, Z. 2010. A cybernetic model for analytic network process, in 2010 International Conference on Machine Learning and Cybernetics (ICMLC), 11-14 July 2010, Qingdao, Vol. 4, 1914-1919. http://dx.doi.org/10.1109/ICMLC.2010.5580528

Czuchry, A. J.; Yasin, M. M. 2003. Managing the project management process, Industrial Management and Data Systems 103(1): 39-46. http://dx.doi.org/10.1108/02635570310456887

Davidson, M.; Leather, P. 2000. Choice or necessity? A review of the role of DIY in tackling housing repair and maintenance, Construction Management \& Economics 18(7): 747-756. http://dx.doi.org/10.1080/014461900433032

Dikmen, I.; Talat Birgonul, M.; Kiziltas, S. 2005. Strategic use of quality function deployment (QFD) in the construction industry, Building and Environment 40(2): 245-255. http://dx.doi.org/10.1016/j.buildenv.2004.07.001

Egbu, C. O. 1999. Skills, knowledge and competencies for managing construction refurbishment works, Construction Management \& Economics 17(1): 29-43. http://dx.doi.org/10.1080/014461999371808

Ertay, T.; Büyüközkan, G.; Kahraman, C.; Ruan, D. 2005. Quality function deployment implementation based on analytic network process with linguistic data: an application in automotive industry, Journal of Intelligent and Fuzzy Systems 16(3): 221-232.

Faisal, M. N.; Banwet, D.; Shankar, R. 2006. Supply chain risk mitigation: modeling the enablers, Business Process Management Journal 12(4): 535-552.

http://dx.doi.org/10.1108/14637150610678113

Fuertes, A.; Casals, M.; Gangolells, M.; Forcada, N.; Macarulla, M.; Roca, X. 2013. An Environmental Impact Causal Model for improving the environmental performance of construction processes, Journal of Cleaner Production 52(1): 425-437. http://dx.doi.org/10.1016/j.jclepro.2013.02.005

Gargione, L. A. 1999. Using quality function deployment (QFD) in the design phase of an apartment construction project, in Proc. of the $7^{\text {th }}$ Annual Conference of the International Group of Lean Construction, 26-28 July 1999, Berkley, CA, USA, 357-368.

Gibb, A. G.; Haslam, R.; Gyi, D. E.; Hide, S.; Duff, R. 2006. What causes accidents?, in Proceedings of the ICE-Civil Engineering 159(6): 46-50.

Goodwin, R. S. 1993. Skills required of effective project managers, Journal of Management in Engineering 9(3): 217226. http://dx.doi.org/10.1061/(ASCE)9742597X(1993)9:3(217)

Gorane, S.; Kant, R. 2013. Modelling the SCM enablers: an integrated ISM-fuzzy MICMAC approach, Asia Pacific Journal of Marketing and Logistics 25(2): 263-286. http://dx.doi.org/10.1108/13555851311314059

Hadad, Y.; Keren, B.; Laslo, Z. 2013. A decision-making support system module for project manager selection ac- cording to past performance, International Journal of Project Management 31(4): 532-541.

http://dx.doi.org/10.1016/j.ijproman.2012.10.004

Hamilton, D. 1991. Records management in engineering firms, Journal of Management in Engineering 7(4): 346-356. http://dx.doi.org/10.1061/(ASCE)9742597X(1991)7:4(346)

Hegazy, T.; Elbeltagi, E; Zhang, K. 2005. Keeping better site records using intelligent bar charts, Journal of Construction Engineering and Management 131(5): 513-521. http://dx.doi.org/10.1061/(ASCE)07339364(2005)131:5(513)

Horner, R.; El-Haram, M.; Munns, A. 1997. Building maintenance strategy: a new management approach, Journal of Quality in Maintenance Engineering 3(4): 273-280. http://dx.doi.org/10.1108/13552519710176881

Hsu, C.-W.; Hu, A. H. 2009. Applying hazardous substance management to supplier selection using analytic network process, Journal of Cleaner Production 17(2): 255-264. http://dx.doi.org/10.1016/j.jclepro.2008.05.004

Hwang, B.-G.; Ng, W. J. 2013. Project management knowledge and skills for green construction: overcoming challenges, International Journal of Project Management 31(2): 272284. http://dx.doi.org/10.1016/j.ijproman.2012.05.004

Jazebi, F.; Rashidi, A. 2013. An automated procedure for selecting project managers in construction firms, Journal of Civil Engineering and Management 19(1): 97-106. http://dx.doi.org/10.3846/13923730.2012.738707

Juan, Y. K.; Perng, Y. H.; Castro-Lacouture, D.; Lu, K. S. 2009. Housing refurbishment contractors selection based on a hybrid fuzzy-QFD approach, Automation in Construction 18(2): 139-144. http://dx.doi.org/10.1016/j.autcon.2008.06.001

Kahraman, C.; Ertay, T.; Büyüközkan, G. 2006. A fuzzy optimization model for QFD planning process using analytic network approach, European Journal of Operational Research 171(2): 390-411. http://dx.doi.org/10.1016/j.ejor.2004.09.016

Kang, H.; Hung, M.; Pearn, W.; Lee, A. H.; Kang, M. 2011. An integrated multi-criteria decision making model for evaluating wind farm performance, Energies 4(11): 2002-2026. http://dx.doi.org/10.3390/en4112002

Karsak, E. E.; Sozer, S.; Alptekin, S. E. 2003. Product planning in quality function deployment using a combined analytic network process and goal programming approach, Computers and Industrial Engineering 44(1): 171-190. http://dx.doi.org/10.1016/S0360-8352(02)00191-2

Keil, M.; Lee, H. K.; Deng, T. 2013.Understanding the most critical skills for managing IT projects: a Delphi study of IT project managers, Information and Management 50(7): 398-414. http://dx.doi.org/10.1016/j.im.2013.05.005

Kerzner, H. 2001. Project management workbook to accompany Project management, a systems approach to planning, scheduling and controlling. $7^{\text {th }}$ ed. New York: Wiley. $448 \mathrm{p}$.

Kumar, S.; Luthra, S.; Haleem, A. 2013. Customer involvement in greening the supply chain: an interpretive structural modeling methodology, Journal of Industrial Engineering International 9(1): 1-13.

http://dx.doi.org/10.1186/2251-712X-9-6

Lam, K.; Zhao, X. 1998. An application of quality function deployment to improve the quality of teaching, International Journal of Quality \& Reliability Management 15(4): 389-413.

Lau, H. S. 2006. The selection of construction project manager by using analytical hierarchy process (AHP): Master thesis. Universiti Teknologi Malaysia, Malaysia. 
Lee, A. H. I.; Kang, H.-Y.; Yang, C.-Y.; Lin, C.-Y. 2010. An evaluation framework for product planning using FANP, QFD and multi-choice goal programming, International Journal of Production Research 48(13): 3977-3997. http://dx.doi.org/10.1080/00207540902950845

Lee, A. H. I.; Lin, C.-Y. 2011. An integrated fuzzy QFD framework for new product development, Flexible Services and Manufacturing Journal 23(1): 26-47. http://dx.doi.org/10.1007/s10696-011-9076-5

Lee, A. H. I.; Kang, H.-Y.; Chang, C.-C. 2011. An integrated interpretive structural modeling - fuzzy analytic network process - benefits, opportunities, costs and risks model for selecting technologies, International Journal of Information Technology \& Decision Making 10(5): 843-871. http://dx.doi.org/10.1142/S0219622011004592

Lee, Y.; Wu, W.; Tzeng, G.-H. 2008. An effective decisionmaking method using a combined QFD and ANP approach, WSEAS Transactions on Business and Economics 5(12): 541-555.

Levin, P. 1998. Construction contract claims, changes \& dispute resolution. Reston, VA: ASCE Press. $255 \mathrm{p}$. http://dx.doi.org/10.1061/9780784402764

Lin, Y.; Cheng, H.-P.; Tseng, M.-L.; Tsai, J. C. C. 2010. Using QFD and ANP to analyze the environmental production requirements in linguistic preferences, Expert Systems with Applications 37(3): 2186-2196. http://dx.doi.org/10.1016/j.eswa.2009.07.065

Ling, F.; Loo, C. 2013. Characteristics of jobs and jobholders that affect job satisfaction and work performance of project managers, Journal of Management in Engineering. http://dx.doi.org/10.1061/(ASCE)ME.1943-5479.0000247

Liu, H. T.; Wang C.-H. 2010. An advanced quality function deployment model using fuzzy analytic network process, Applied Mathematical Modelling 34(11): 3333-3351. http://dx.doi.org/10.1016/j.apm.2010.02.024

Liu, H. T.; Tsai, Y. L. 2012. A fuzzy risk assessment approach for occupational hazards in the construction industry, Safety Science 50(4): 1067-1078.

http://dx.doi.org/10.1016/j.ssci.2011.11.021

Meredith, J. R.; Mantel, S. J. Jr. 2011. Project management: a managerial approach. Hoboken, NJ: Wiley. 600 p.

Michael, A. O.; Razak, A. R. 2013. The study of claims arising from building collapses: case studies from Malaysia, Nigeria, Singapore and Thailand, Civil and Environmental Research 3(11): 113-129.

Mohammadi, F.; Nateghi, F.; Pourhejazi, S. P.; Abdullah, A.; Gandomi, N.; Sadi, M. K. 2014. Part deployment model using combined quality function deployment and cybernetic fuzzy analytic network process, Indian Journal of Science \& Technology 7(1), in Press.

MS2318:2012 Malaysian Code of Practice for Building Demolition. Malaysia: Ministry of Public Works, 2012. 38 p.

Müller, R.; Turner, R. 2007. The influence of project managers on project success criteria and project success by type of project, European Management Journal 25(4): 298-309. http://dx.doi.org/10.1016/j.emj.2007.06.003

Ochieng, E. G.; Price, A. D. F.; Ruan, X.; Egbu, C. O.; Moore, D. 2013. The effect of cross-cultural uncertainty and complexity within multicultural construction teams, Engineering, Construction and Architectural Management 20(3): 307-324. http://dx.doi.org/10.1108/09699981311324023

Ofori, G.; Dulaimi, M. F.; Ling, F. Y. 2004. Improving performance of construction industry in Singapore: motivators, enablers and lessons for developing countries, Journal of Construction Research 5(02): 267-289.

http://dx.doi.org/10.1142/S1609945104000188
Ogunlana, S.; Siddiqui, Z.; Yisa, S.; Olomolaiye, P. 2002. Factors and procedures used in matching project managers to construction projects in Bangkok, International Journal of Project Management 20(5): 385-400. http://dx.doi.org/10.1016/S0263-7863(01)00017-5

Opricovic, S.; Tzeng, G. 2004. Compromise solution by MCDM methods: a comparative analysis of VIKOR and TOPSIS, European Journal of Operational Research 156(2): 445-455. http://dx.doi.org/10.1016/S0377-2217(03)00020-1

Pal, D.; Ravi, B.; Bhargava, L. 2007. Rapid tooling route selection for metal casting using QFD-ANP methodology, International Journal of Computer Integrated Manufacturing 20(4): 338-354. http://dx.doi.org/10.1080/09511920600883229

Partovi, F. Y.; Corredoira, R. A. 2002. Quality function deployment for the good of soccer, European Journal of Operational Research 137(3): 642-656. http://dx.doi.org/10.1016/S0377-2217(01)00072-8

Prieto, B. 2013. Establishing and building leadership skills, Leadership and Management in Engineering 13(3): 209211. http://dx.doi.org/10.1061/(ASCE)LM.19435630.0000235

Raharjo, H.; Brombacher, A.; Xie, M. 2008. Dealing with subjectivity in early product design phase: a systematic approach to exploit Quality Function Deployment potentials, Computers and Industrial Engineering 55(1): 253-278. http://dx.doi.org/10.1016/j.cie.2007.12.012

Rashidi, A.; Jazebi, F.; Brilakis, I. 2011. Neurofuzzy genetic system for selection of construction project managers, Journal of Construction Engineering and Management 137(1): 17-29. http://dx.doi.org/10.1061/(ASCE)CO.1943-7862.0000200

Roethlisberger, F. J.; Dickson, W. J. 2003. Management and the worker. London: Routledge. 615 p.

Saaty, T. L. 1990. How to make a decision: the analytic hierarchy process, European Journal of Operational Research 48(1): 9-26. http://dx.doi.org/10.1016/0377-2217(90)90057-I

Saaty, T. L. 2003. Decision-making with the AHP: why is the principal eigenvector necessary?, European Journal of Operational Research 145(1): 85-91.

http://dx.doi.org/10.1016/S0377-2217(02)00227-8

Saaty, T. L. 2004. Fundamentals of the analytic network process - Dependence and feedback in decision-making with a single network, Journal of Systems Science and Systems Engineering 13(2): 129-157. http://dx.doi.org/10.1007/s11518-006-0158-y

Saaty, T. L. 2008. The analytic network process, Iranian Journal of Operations Research 1(1): 1-27.

Saaty, T. L. 2009. Theory and applications of the Analytic Network Process: Decision making with benefits, opportunities, costs and risks. Pittsburgh: RWS Publications. 352 p.

Saaty, T. L.; Vargas, L. G. 2001. Models, methods, concepts \& applications of the Analytic Hierarchy Process. International Series in Operations Research \& Management Science, Vol. 34. Springer, US. 333 p. http://dx.doi.org/10.1007/978-1-4615-1665-1

Sekaran, U.; Bougie, R. 2010. Research methods for business. New York: Wiley. 488 p.

Senescu, R. R.; Haymaker, J. R.; Meza, S.; Fischer, M. A. 2014. Design process communication methodology: improving the effectiveness and efficiency of collaboration, sharing, and understanding, Journal of Architectural Engineering 20(1): 04014039.

http://dx.doi.org/10.1061/(ASCE)AE.1943-5568.0000122 
Serpell, A.; Wagner, R. 1997. Application of quality function deployment (QFD) to the determination of the design characteristics of building apartments, in L. Alarcon (Ed.). Lean construction. Rotterdam: A. A. Balkema, 355-363. http://dx.doi.org/10.4324/9780203345825_Application_of _Quality_Function_Deployment_(QFD)

Singh, M. D.; Kant, R. A. 2007. Knowledge management barriers: An interpretive structural modeling approach, in 2007 IEEE International Conference on Industrial Engineering and Engineering Management, 2-4 December 2007, Singapore, 2091-2095. http://dx.doi.org/10.1109/IEEM.2007.4419560

Sun, M.; Meng, X. 2009. Taxonomy for change causes and effects in construction projects, International Journal of Project Management 27(6): 560-572. http://dx.doi.org/10.1016/j.ijproman.2008.10.005

Taghizadeh, H. M. E. sis. 2013. Supplier's selection in supply chain with combined QFD and ANP approaches (case study), Research Journal of Recent Sciences 2(6): 66-76.
Tavakkoli-Moghaddam, R.; Mousavi, S. M.; Heydar, M. 2011. An integrated AHP-VIKOR methodology for plant location selection, in IJE Transactions B: Applications 24(2): 127-137.

Tian, Y.; Peng, Y. 2010. Impact of communication on supplier integration and organizational performance, in ICLEM 2010: 1923-1929.

Warfield, J. N. 1974. Developing interconnection matrices in structural modeling, IEEE Transactions on Systems, Man and Cybernetics SMC-4(1): 81-87. http://dx.doi.org/10.1109/TSMC.1974.5408524

Yang, Y. Q.; Wang, S. Q.; Dulaimi, M.; Low, S. P. 2003. A fuzzy quality function deployment system for buildable design decision-making, Automation in Construction 12(4): 381-393. http://dx.doi.org/10.1016/S0926-5805(03)00002-5

Yasin, M. M.; Czuchry, A. J.; Alavi, J. 2002. Project management practices: Then and now, Thunderbird International Business Review 44(2): 253-262. http://dx.doi.org/10.1002/tie.10013

Farahbod MOHAMMADI. Is currently $\mathrm{PhD}$ student at faculty of civil engineering Universiti Teknologi Malaysia (UTM). He obtained BSc in Civil Engineering and MSc in Construction Management from Islamic Azad University (IAU) and (UTM) respectively. He also serves as faculty member (lecturer) at IAU - Fouman \& Shaft branch. His main research interests include application of multiple criteria decision making theories in construction domain, construction technology, demolition safety assessment and environmental aspect evaluation associated with demolition activities.

Mohammadali Kazerooni SADI. Is currently PhD student at Department of Structure and Materials, Universiti Teknologi Malaysia. He received his Diploma in Civil Engineering from Shahid Bahonar University of Kerman, Iran, and his MSc in Construction Management from Universiti Teknologi Malaysia, in 2003 and 2008. He also serves as lecturer at Islamic Azad University of Science and Research, Kerman. His research interests include Construction and Project Management, Demolition Engineering, Sustainable Construction, and Building Information Modeling.

Fatemeh NATEGHI. Is currently PhD student at faculty of civil engineering, Universiti Teknologi Malaysia (UTM). She is a holder of BSc in water engineering from Shahr-e-Kord University (SKU) and M.Sc in construction management from UTM. Fatemeh also served as a research assistant during her PhD study. Her research focuses on application of decision making theories in construction domain and environmental management of demolition project.

Arham ABDULLAH. Obtained his Bachelor of Civil Engineering (BEng) in 1998 and Master of Engineering (MEng Engineering Management) in 1999 from Universiti Teknologi Malaysia (UTM). He completed his PhD from Loughborough University United Kingdom in 2003 in the area of Building and Structural Demolition. Currently he is an Associate Professor in Faculty of Civil Engineering UTM. He also has been appointed as the Deputy Director (Innovation) at Innovation and Commercialisation Centre, (ICC) UTM. As professional membership, he is an Affiliate Member of Institute of Demolition Engineers United Kingdom, and Graduate Member of Board of Engineer Malaysia (BEM) and Institute of Engineers Malaysia (IEM). Construction Industry Development Board (CIDB) has appointed him as a co-opted member in developing the Malaysian Code of Practice for Building Demolition MS2318:2012 and as a consultant in developing a training module for demolition contractors in Malaysia. He also has assisted Majlis Bandaraya Petaling Jaya (MBPJ) in developing the Petaling Jaya Guideline for Building Demolition. Since 2004, he is actively practicing his expertise as a demolition consultant in many demolition projects in Malaysia. His research interests are mainly in Building and Structural Demolition, IT Application in Construction (Artificial Intelligent, Decision Support System, Expert System, Database Management System) and Construction Technology \& Management.

Martin SKITMORE. Is currently a Professor in the School of Civil Engineering \& Built Environment, Queensland University of Technology having held a personal chair at the UK University of Salford's 6 Star rated Department of Surveying (now School of the Built Environment). He is a former editor-in-chief of the Journal of Construction Innovation and a member of several international journal editorial boards. With a Scopus 16 year h-index of 19, he has also authored/coauthored over 190 refereed journal papers on construction economics and project management in addition to many refereed conference papers. 